\title{
From the Editor-in-Chief's Desk: The "Workplace-During-Recession" Reminding Us of Employee Rights and Responsibilities
}

\author{
Margaret H. Vickers
}

Published online: 23 December 2008

(C) Springer Science + Business Media, LLC 2008

One cannot turn on the television or radio, or read a newspaper or magazine, without being reminded of the financial crisis that is reported to be swallowing the Western world. We are now informed on a daily basis that we are either already in a recession (e.g., if you live in the US) or headed for one at a heart-stopping rate (e.g., if you live in Australia). Sadly, the almost uniform and collective (and often unhelpful) response to the R-word in the business, public, and not-for-profit realms is to get rid of workers - fast.

And this is not a new response. Redundancies (voluntary or otherwise), layoffs, restructures, downsizing, cutbacks, re-engineering, recasting, re-profiling, re-energizing, or resizing (Micklethwait and Wooldridge 1996) are all examples of the most popular and familiar euphemisms for the most popular and familiar cost-cutting strategies used worldwide. Downsizing and redundancies are now seen as normal practice in organizational life (Orlando 1999).

Job losses as a result of the R-word (whether it has arrived officially or is still on its way) are now being heralded at every turn. Many workplaces take on a subtle but definite shift in identify when the R-word is on the horizon: they become the "workplace-duringrecession." However, the outcome of this identity additive is less than subtle.

For workers who are marginalized for any reason at all—and let's face it, that's most of us - it's a time to be nervous. What might have been whined about by workers before their workplaces morphed into the workplace-during-recession suddenly becomes acceptable to workers trying to keep their jobs. We know that the predominant cost-cutting strategy that accompanies the workplace-during-recession generally involves getting rid of at least some of the workers and their jobs. And none of us workers like the sound of that.

At times like these, scholars of organizations, of organizing, and of the rights and responsibilities of workers in organizations need to be especially vigilant. We need to be especially aware of the rights of workers at the margins and those who are vulnerable in our workplaces. Workers at the margins, as with other vulnerable workplace or social groups, are often those who don't fit in, who are different, or who are less able than most to protect their own interests. They are often those in peril, especially at work.

M. H. Vickers $(\bowtie)$

University of Western Sydney, Sydney, Australia

e-mail: m.vickers@uws.edu.au 
And who are the workers at the margins? Well, there are plenty of them to choose from, depending on the context of your search and the viewfinder you choose: older workers; younger workers; workers with disability or chronic illness; workers of the "wrong" gender, ethnicity, spoken-language preference, sexual orientation, or religious background; and other workers who, for whatever reason, just don't seem to fit in. They might be too outspoken, confident, successful, talented, or qualified. Conversely, they might be too unassertive, unassuming, uncertain, unsure, or lacking in the "right" qualifications.

In the workplace-during-recession, all of these individuals should be discomforted by the news headlines in the first instance, and the rumors, closed-door meetings, and upbeat managerialist rhetoric that inevitably follows. Workers at the margins, vulnerable workers, are often (but not always) those who feel that they are likely to be the first targeted when things get tough. And they might just be right. Or they might just as easily find they are targeted - and learn a rather harsh lesson - even though they hadn't previously considered themselves one of the usual candidates. Vulnerable workers aren't always fully aware of their status or the danger they face; they may have no idea at all why they are being targeted or why indeed they even reside at the margins at all. The workplace-during-recession makes all workers more vulnerable than usual.

The workplace-during-recession can also be a place where the ugly side of organizational life asserts, or even re-asserts, itself. Workers (yes, managers too) seem to lose sight of the need to maintain civility and reason when the R-word arises. Workplaces can be places of harm and hurt during times of plenty. However, the pressures of recession and the need for change can also effect an intensification of unwelcome harshness, a loss of humanity, and a lack of compassion.

We have known for some time about the increasingly recognized phenomena of the alienating workplace (Blauner 1964), the increasingly abusive organization (Powell 1998), the increase in workplace violence (Bryant and Cox 2003), workplace bullying and mobbing (e.g., Zapf and Einarsen 2003, 2005; Hutchinson et al. 2008), as well as the rise in incivility at work (Andersson and Pearson 1999), including mistreatment (Lim and Cortina 2005), insults (Gabriel 1998), and rudeness (Pearson 1999; Johnson and Indvik 2001). As organizations find themselves lurching toward being the different animal they become as a workplace-during-recession, it is vital that scholars and practitioners remain vigilant so that the negative phenomena noted above don't escalate as the context of recession might demand.

In this issue, Employee Responsibilities and Rights Journal showcases international perspectives that may prove helpful to those who are keeping a close eye on employee rights and responsibilities, especially within the workplace-during-recession. Howard's article opens this issue with commentary about workplace violence in a large public university in the Midwest of the U.S. This article includes advice about actions organizations should take if workplace violence does occur.

Luthar and colleagues use social identity theory to explore the role of race stereotypes and their influence on sexual harassment outcomes. They argue that the stereotypes of African-American women tend to be much more negative than those of white women, and that these negative stereotypes serve to further marginalize African-American women who have been subject to sexual harassment.

Mello's article discusses the strategy of "salting" used by unions, especially those with declining memberships, to organize employees from the inside, rather than the outside. Mello discusses the US Supreme Court ruling that, under the National Labor Relations Act, "salts" cannot be discriminated against solely on the basis of their status as salts. He also includes an examination of some employer responses that counter salting efforts. 
Next, we move to the Perspectives Section where we find a discussion of the working conditions of child workers in Turkey, which is introduced by the Editor of Perspectives, Devinatz. Child labor remains an area of significant interest and concern, especially in developing nations. This article by Akin is likely to be of huge interest to readers of Employee Responsibilities and Rights Journal, especially those concerned with organizations and organizing in developing countries - in this case, Turkey. It remains the case that millions of children around the world continue to work in conditions that may be harmful to their physical, mental, emotional, social, and cultural development.

Finally, this issue concludes with a book review from Australia. This article examines the edited collection, The Australian Charter of Employment Rights, and will be of eminent interest to scholars of employment and employee rights and responsibilities, not only in Australia, but also worldwide. Much of the book's content is based on international conventions concerned with equitable principles which the various authors suggest should govern our workplaces, such as workplaces free of discrimination, dignity at work, fair minimum standards, and effective dispute resolution. As the R-word gathers momentum, a collection such as this will be a useful reference for many of us.

In closing, I reiterate my invitation to contact me regarding any queries you might have about a potential article or submission for the journal. I also welcome your ideas and thoughts about potential special issues of interest to our international readership.

I also highlight our expanded Editorial Board that includes an even wider gathering of outstanding international scholars to support authors and readers of Employee Responsibilities and Rights Journal. It is with great pleasure I welcome the new Editorial Board members to complement the strength already in place. Both the new and continuing Editorial Board members are committed to and focused upon supporting and working with authors to assist them in bringing their work to publishable standard, and to offer readers and contributors exciting opportunities to explore the challenges of employee rights and responsibilities.

I hope you enjoy this issue, and look forward to hearing your feedback and comments about the journal.

\section{References}

Andersson, L. M., \& Pearson, C. M. (1999). Tit for tat? The spiraling effect of incivility in the workplace. Academy of Management Review, 24(3), 452-471.

Blauner, R. (1964). Alienation and freedom: The factory worker and his industry. Chicago and London: The University of Chicago Press.

Bryant, M., \& Cox, J. W. (2003). The telling of violence: Organizational change and atrocity tales. Journal of Organizational Change Management, 16(5), 567-583.

Gabriel, Y. (1998). An introduction to the social psychology of insults in organizations. Human Relations, 51 (11), 1329-1354.

Hutchinson, M., Jackson, D., Wilkes, L., \& Vickers, M. H. (2008). A new model of bullying in the nursing workplace: Organizational characteristics as critical antecedents. Advances in Nursing Science, 31(2), $60-71$.

Johnson, P. R., \& Indvik, J. (2001). Slings and arrows of rudeness: Incivility in the workplace. Journal of Management Development, 20(8), 705-713.

Lim, S., \& Cortina, L. M. (2005). Interpersonal mistreatment in the workplace: The interface and impact of general incivility and sexual harassment. Journal of Applied Psychology, 9(3), 483-496.

Micklethwait, J., \& Wooldridge, A. (1996). The witch doctors: What the management gurus are saying, why it matters and how to make sense of it. London: Mandarin Paperbacks.

Orlando, J. (1999). The fourth wave: The ethics of corporate downsizing. Business Ethics Quarterly, 9(2), 295-314.

Pearson, C. (1999). Rude managers make for bad business. Workforce, 78(3), 18. 
Powell, G. N. (1998). The abusive organisation. Academy of Management Executive, 12(2), 95-96.

Zapf, D., \& Einarsen, S. (2003). Individual antecedents of bullying: Victims and perpetrators. In S. E. Einarsen, H. Hoel, D. Zapf, \& C. Cooper (Eds.), Bullying and emotional abuse in the workplace: International perspectives in research and practice (pp. 165-184). London: Taylor and Francis.

Zapf, D., \& Einarsen, S. E. (2005). Mobbing at work: Escalated conflict in organisations. In S. Fox, \& P. E. Spector (Eds.), Counterproductive work behaviours (pp. 237-270). Washington, D.C.: American Psychological Association. 